\title{
First record of Compsilura concinnata (Meigen, 1824) (Diptera: Tachinidae) attacking Orgyia trigotephras (Boisduval, 1829) in Tunisia
}

\author{
Sonia Hammami ${ }^{1}$, Islem Yangui ${ }^{1}{ }^{2 *}$, Olfa Ezzine ${ }^{3}$, Cezary Bystrowski ${ }^{4}$, Katarzyna Sikora $^{4}$ and \\ Mohamed Lahbib Ben Jamâa'
}

\begin{abstract}
Background: The polyphagous tachinid Compsilura concinnata is an endoparasitoid fly recorded as attacking larvae of Lepidoptera and Hymenoptera. Larvae of Orgyia trigotephras [Lepidoptera: Erebidae] were collected from northern Tunisia and reared in the laboratory.

Results: Adult flies that emerged from these larvae were identified on the basis of morphological description and DNA analysis (PCR) as Compsilura concinnata.

Conclusion: Compsilura concinnata is recorded here for the first time from Orgyia trigotephras in Tunisia. This species could be of great interest as a potential biological control agent of pests in Tunisia and neighboring countries.
\end{abstract}

Keywords: Endoparasitoid, Larvae. Orgyia trigotephras, DNA analysis, Tunisia

\section{Background}

The Tachinidae are the second largest family of the order Diptera and the most important group of entomophagous parasitoids Mellini (1990). Most tachinid species are endoparasitoids of many insect orders' host orders English-Loeb et al. (1990), predominantly Lepidopteran larvae, Stireman et al. (2006), and the majority are ovoviviparous, Evenhuis et al. (2008). Among this family, the genus Compsilura Bouché, 1834, is the smallest one of the tribe Blondeliini (Tachinidae: Exoristinae) including three species, namely Compsilura solitaria Curran., C. samoaensis Malloch. and C. concinnata Meigen (Crosskey 1973; 1976; O'Hara and Cerretti 2016). The species C. concinnata was described for the first time by Meigen (1824) from Germany. It is an endoparasitoid of endoparasitoid of larvae of the Lepidoptera, Hymenoptera

\footnotetext{
*Correspondence: yanguiislam@gmail.com

${ }^{1}$ National Research Institute of Rural Engineering, Water and Forests (INRGREF), LR161INRGREF01-Laboratory of Management and Valorization of Forest Resources, University of Carthage, Bp. 10, 2080 Ariana, Tunisia Full list of author information is available at the end of the article
}

and Coleoptera (Herting 1960; Arnaud 1978; Tschorsnig 2017).

In this paper, we combined morphological and molecular data to diagnose and confirm the parasitoid species Compsilura concinnata (Meigen 1824) attacking larvae of the Erebidae, Orgyia trigotephras [Lepidoptera: Erebidae], and to report it for the first time in Tunisia.

\section{Methods}

Investigations were conducted in northern Tunisia from 2013 to 2018. A total of 1060 larvae of Orgyia trigotephras were collected (with 926 larvae from Jebel Abderrahmane (Cap-Bon, alt. $432 \mathrm{~m} ; 36^{\circ} 52^{\prime} \mathrm{N}, 10^{\circ} 48^{\prime} \mathrm{E}$ ) and 134 larvae from Dam Ziatine (Sejnane, alt. $48 \mathrm{~m} ; 37^{\circ} 11^{\prime} \mathrm{N}$, $9^{\circ} 11^{\prime} \mathrm{E}$ ). Each larva was kept individually in a plastic box $(30 \times 70 \mathrm{ml})$ at $25 \pm 2{ }^{\circ} \mathrm{C}$ and reared on fresh leaves of its host plant, Quercus coccifera (Fagaceae). A periodic check of rearing boxes was carried out, and we noticed the emergence of parasitoids from all larval instars. Adult flies were stored in ethanol (95\%) until identification. The morphological characters of adult flies were described 
using keys of Shima (1997); Tschorsnig and Herting (1994); Tschorsnig and Richter (1998).

For specific final recognition, molecular analysis of 1-3 legs of the 8 specimens of flies was carried out by amplification of $650 \mathrm{pb}$ fragment of the mitochondrial cytochrome $\mathrm{c}$ oxidase gene subunit 1 (COX1) using the universal primers LCO1490/HCO2198 (Folmer et al. 1994). DNA extraction was carried out using the Syngen DNA Mini Kit (Syngen, Poland) according to the manufacturer's instructions. Polymerase chain reaction (PCR) amplification mix was prepared in $25 \mu$ l contained $1 \times$ PCR Buffer (Taq PCR Core Kit, QIAGEN), $1.5 \mathrm{mM}$ $\mathrm{MgCl} 2,0.4 \mathrm{mM}$ of each dNTP, $0.2 \mu \mathrm{M}$ of each primer, $1 \mathrm{U}$ of Taq polymerase and 10-20 ng of template DNA. Thermal cycling was executed on a T gradient thermal cycler (Bio-Rad) with an initial denaturation at $96^{\circ} \mathrm{C}$ for $3 \mathrm{~min}$, followed by 40 cycles of denaturation at $96^{\circ} \mathrm{C}$ for $30 \mathrm{~s}$, annealing at $48{ }^{\circ} \mathrm{C}$ for $56 \mathrm{~s}$, extension at $72{ }^{\circ} \mathrm{C}$ for $1 \mathrm{~min}$ and $20 \mathrm{~s}$, and a final extension at $72{ }^{\circ} \mathrm{C}$ for $10 \mathrm{~min}$. Amplicons were analyzed by electrophoresis, visualized in a $1 \%$ agarose gel stained with the GelRed ${ }^{\circledR}$ dye (Biotium, USA) and purified using the CleanUp Kit (A\&A Biotechnology, Poland). Sequencing of the purified amplification products was performed at Genomed Company (Warsaw, Poland). The obtained sequences were analyzed using the Basic Local Alignment Search Tool Nucleotide (BLASTN) searches at GenBank (National Center for Biotechnology Information, https://www.ncbi.nlm. nih.gov/) in order to determine the closest matches and confirm the morphological identification. To perform phylogenetic analysis, the generated sequences were supplemented with additional sequences of Compsilura concinnata specimens obtained from GenBank and other species from Tachindae family used as outgroups. The phylogenetic tree was carried out by using the Maximum Likelihood Method based on the Kimura 2-parameter model (Kimura 1980). The analysis involved 18 nucleotide sequences and was conducted in MEGA v.6.

\section{Results}

The morphological description showed that the flies have eyes densely covered with long hairs (Fig. $1 \mathrm{a}-\mathrm{c}$ ). Above the vibrissa, strong upright bristles reach further than the middle of the facial ridges (Fig. 1b). Ocellar are setae absent (Fig. 1c). The third antennal segment on its base did not noticeably pull forward. Scutum with four pairs of post-sutural dorso-central bristles behind the suture. The third and fourth female tergites are ventrally compressed, and the 7th abdominal sternite is modified into a piercer (Fig. 1d).

PCR amplification of the partial sequence of the barcoding region of the cytochrome oxidase subunit I gene (COI) resulted in a $623 \mathrm{bp}$ fragment for each specimen.

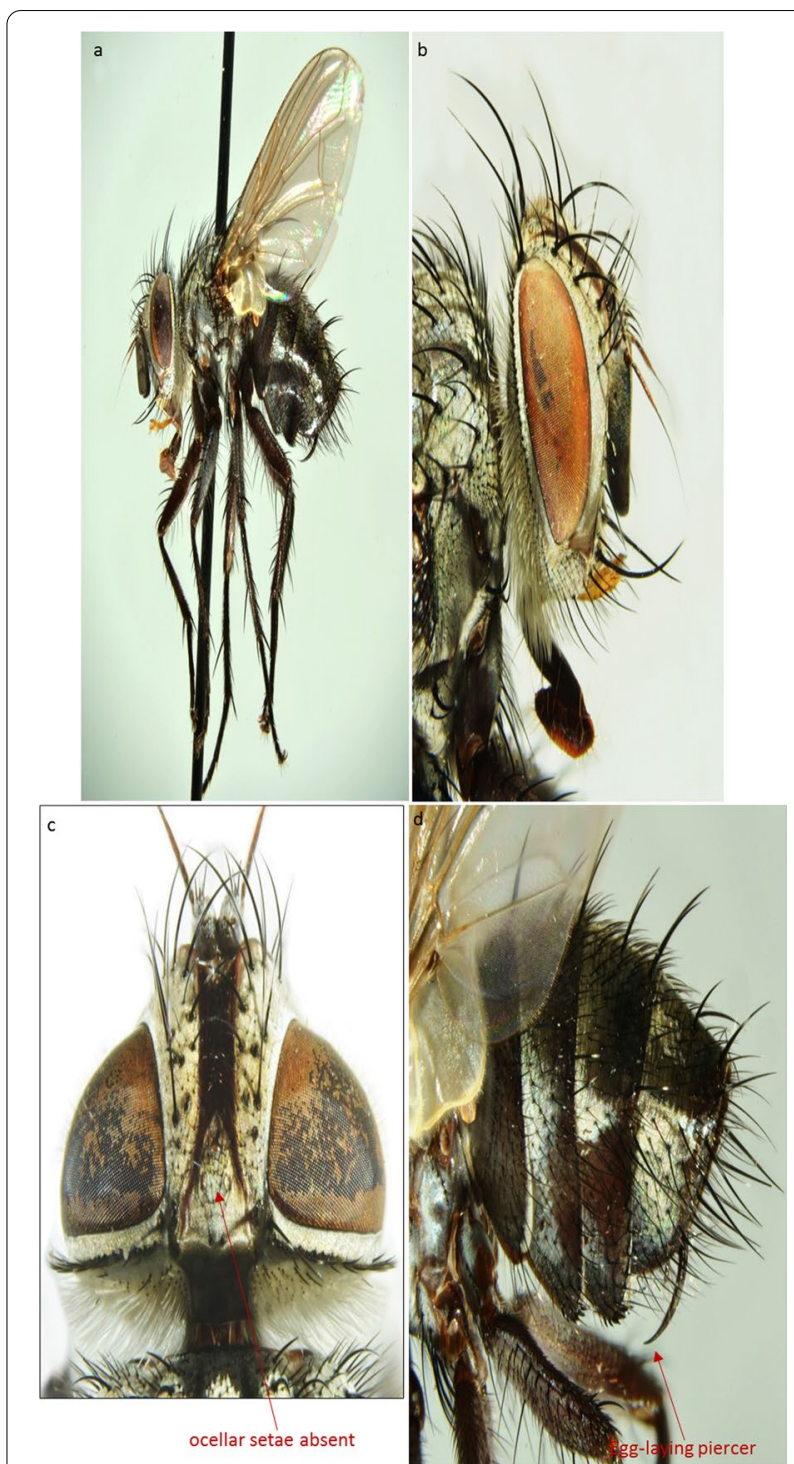

Fig. 1 Compsilura concinnata; a Adult; b head; c Ocellar setae; d abdomen
The sequencing of these fragments showed that the 8 specimens shared $100 \%$ identity at all sequenced sites. BLAST searches in GenBank revealed that the eight generated sequences had 100\% homology with sequences of Compsilura concinnata (LC516575 and LC516576) originating from Spain.

The phylogenetic tree with the highest log likelihood $(-1767.5128)$ is shown in Fig. 2. The analyzed specimens clustered unambiguously with Compsilura concinnata specimens (LC516575, LC516576, LC516571, and LC516564) with $99 \%$ of support in the ML and formed a cluster clearly separate from outgroups (Fig. 2). Accordingly, this confirms the identity of the eight specimens 


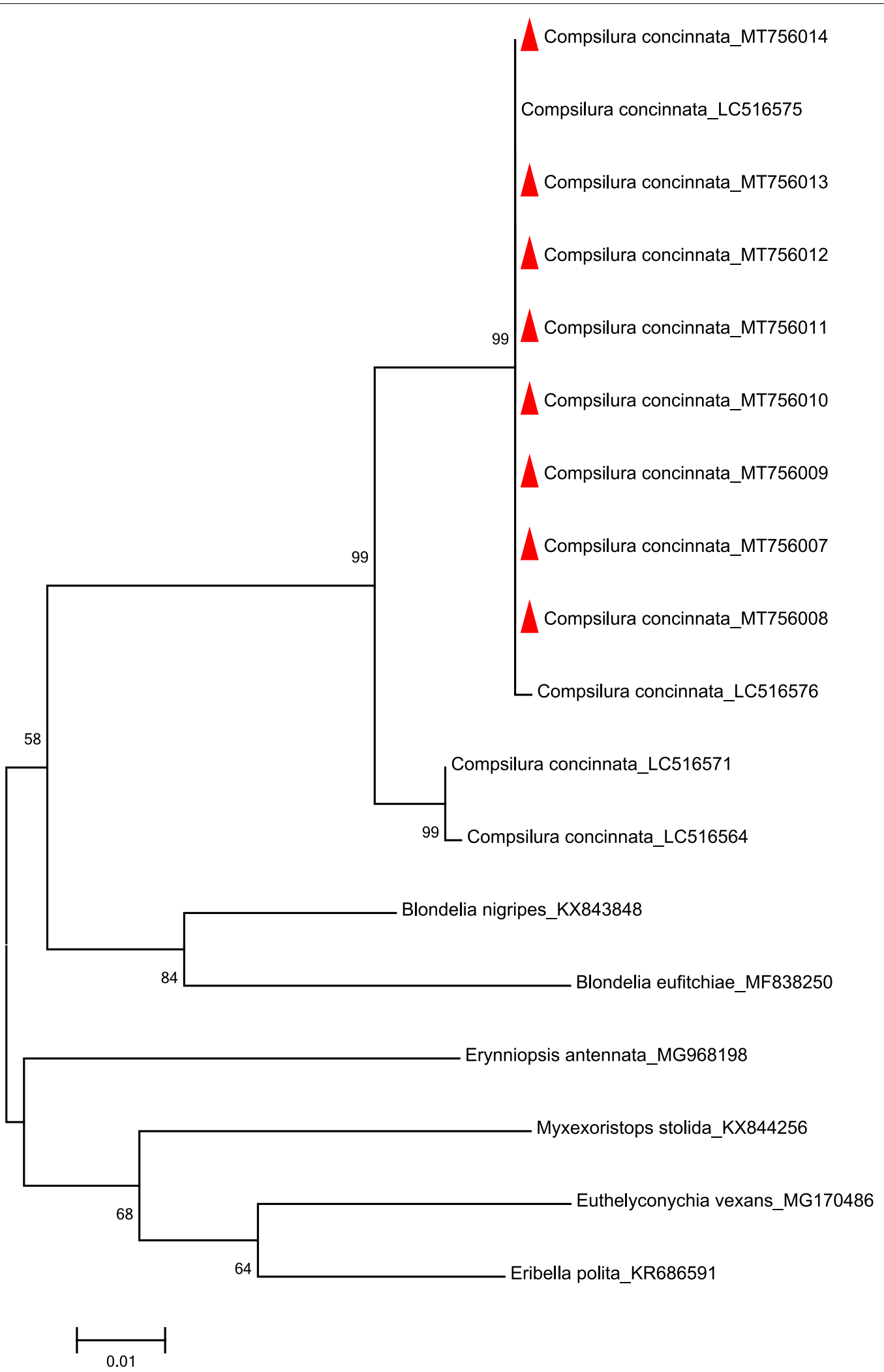

Fig. 2 Molecular phylogenetic analysis of Compsilura concinnata by maximum likelihood method using the Kimura 2-parameter model (Kimura 1980) 
as Compsilura concinnata. The generated sequences were deposited in GenBank under the following accession numbers: MT756007, MT756008, MT756009, MT756010, MT756011, MT756012, MT756013 and MT756014 (Fig. 2).

\section{Discussion}

In Tunisia, the diversity of tachinid has been less studied for a long time but many updates to the host list were provided afterward (Tschorsnig 2017). Most tachinid species are able to parasitize only one or a few closely related host species of insects. From 1906 to 1911, Compsilura concinnata was one of the first parasite enemies of the gypsy moth (Lymantria dispar) and the browntail moth (Euproctis chrysorrhoea) to be obtained from Europe (Burgess 1929). It was introduced in the northeastern United States to control the populations of gypsy moth, and brown-tailed moth, (Sabrosky and Reardon 1976). This species was recorded on about 275 host species (Herting 1960; Arnaud 1978; Tschorsnig 2017) distributed in the Palaearctic region, particularly in Europe and North Africa to Japan. Compsilura concinnata was introduced in the northeastern United States to control the populations of gypsy moth, Lymantria dispar and brown tail moth, Euproctis chrysorrhoea (Sabrosky and Reardon 1976). In Tunisia, the species was observed for the first time in 2013 as a parasitoid on larvae of Orgyia trigotephras.

\section{Conclusions}

For the first time, the tachinid fly, Compsilura concinnata is recorded here attacking the erebid caterpillar, Orgyia trigotephras in Tunisia. This species could be of great interest as a potential biological control agent of pests in Tunisia and neighboring countries.

\section{Abbreviations}

DNA: Deoxyribonucleic acid; PCR: Polymerase chain reaction; COX1: The mitochondrial cytochrome c oxidase gene subunit 1; COI: Cytochrome c oxidase 1; MEGA V.6: The molecular evolutionary genetics analysis version 6.

\section{Acknowledgements}

Not applicable.

\section{Authors' contributions}

SH designed the project, performed the field and laboratory work and wrote the paper. IY performed the analysis of molecular data and reviewed the paper. OE planned and designed the research experiments, performed data analysis and reviewed the paper. CB and KS performed the morphological identification of Diptera parasitoids and reviewed the paper. MLB supervised and provided funding acquisition, administration and validation. All authors read and approved the final manuscript.

\section{Funding}

Not applicable.

\section{Availability of data and materials}

The datasets used and/or analyzed during the current study are available from the corresponding author on reasonable request.

\section{Declarations}

Ethics approval and consent to participate

Not applicable.

\section{Consent for publication}

Not applicable.

\section{Competing interests}

The authors declare that they have no competing interests.

\section{Author details}

${ }^{1}$ National Research Institute of Rural Engineering, Water and Forests (INRGREF), LR161INRGREF01-Laboratory of Management and Valorization of Forest Resources, University of Carthage, Bp. 10, 2080 Ariana, Tunisia. ${ }^{2}$ National Institute of Applied Sciences and Technology (INSAT), UR17ES22-Laboratory of Nanobiotechnology and Valorization of Medicinal Phytoresources, University of Carthage, Tunis Cedex, Tunisia. ${ }^{3}$ National Research Institute of Rural Engineering, Water and Forests (INRGREF)-Laboratory of Forest Ecology-LR161INRGREF03, University of Carthage, Bp. 10, 2080 Ariana, Tunisia. ${ }^{4}$ Department of Forest Protection in Sękocin Stary, Forest Research Institute, Bp.05-090, Raszyn, Poland.

Received: 11 November 2021 Accepted: 15 February 2022

Published online: 22 February 2022

\section{References}

Arnaud PH Jr (1978) A host-parasite catalog of North American Tachinidae (Diptera). U S Dept Agric Misc Publ 1319:1-860

Bouché PF (1834) Naturgeschichte der Insekten, besonders in Hinsicht ihrer ersten Zust"ande als Larven und Puppen. Erste Lieferung. Nicolai, Berlin. v $+[1]+216 \mathrm{pp} .+10 \mathrm{pls}$

Burgess AF (1929) Imported insect enemies of the gypsy moth and the brown-tail moth. Tech Bull US Dept Agric 86:1-147

Crosskey RW (1973) A conspectus of the Tachinidae (Diptera) of Australia, including keys to the supraspecific taxa and taxonomic and host catalogues. Bull Br Mus Nat Hist (Ent) Suppl. 21. 221

Crosskey RW (1976) A taxonomic conspectus of the Tachinidae (Diptera) of the Oriental Region. Bull Br Mus Nat Hist (Ent) Suppl. 26. 357

English-Loeb GM, Karban R, Brody AK (1990) Arctiid larvae survive attack by a tachinid parasitoid and produce viable offspring. Ecol Entomol 15:361-362

Evenhuis NL, Pape T, Pont AC (2008) The problems of subsequent typification in genus-group names and use of the Zoological Record: a study of selected post-1930 Diptera genus-group names without type species designations. Zootaxa 1912:1-44

Folmer O, Black M, Hoeh W, Lutz R, Vrijenhoek R (1994) DNA primers for amplification of mitochondrial cytochrome $C$ oxidase subunit I from diverse metazoan invertebrates. Mol Mar Biol Biotechnol 3:294-299

Herting B (1960) Biologie der westpal aarktischen Raupenfliegen. Dipt Tachinidae Monogrn Angew Ent 16:1-188

Kimura M (1980) A simple method for estimating evolutionary rate of base substitutions through comparative studies of nucleotide sequences. $J$ Mol Evol 16:111-120

Meigen JW (1824) Systematische Beschreibung der bekannten europ"aischen zweiflügeligen Insekten. Vierter Theil. Schultz-Wundermann, Hamm, xii $+428 \mathrm{pp}$

Mellini E (1990) Sinossi di biologia dei Ditteri Larvevoridi. Boll. Ist Entomol Guido Grandi Stud Bologna 45:1-38

O'Hara JE, Cerretti P (2016) Annotated catalogue of the Tachinidae (Insecta, Diptera) of the Afrotropical Region, with the description of seven new genera. Zookeys 575:1-344 
Sabrosky CW, Reardon RC (1976) Tachinid parasites of the gypsy moth Lymantria dispar with Keys to adults and puparia. Misc Publ Entomol Soc Am 10(2):126

Shima H (1997) Taxonomic notes on Oriental Tachinidae (Insecta, Diptera) I: Blondeliini. Bull Grad Sch Soc Cult Stud Kyushu Univ 3:169-186

Stireman JO, O'hara JE, Montywood D (2006) TACHINIDAE: evolution behavior and ecology. Annu Rev Entomol 51:525-55

Tschorsnig HP (2017) Preliminary host catalog of Palaearctic Tachinidae (Diptera) http://www.nadsdiptera.org/Tach/WorldTachs/CatPalHosts/Home. html. Cited 11 November 2019.

Tschorsnig HP, Herting B (1994) The Tachinids (Diptera: Tachinidae) of Central Europe: identification keys for the species and data on distribution and ecology. Stutt Beitr NaturkSer A 506:47-90

Tschorsnig HP, Richter VA (1998) Family Tachinidae. In: Papp L, Darvas B (eds) Contributions to a manual of Palaearctic Diptera, vol 3. Science Herald, Budapest, pp 691-827

\section{Publisher's Note}

Springer Nature remains neutral with regard to jurisdictional claims in published maps and institutional affiliations.

\section{Submit your manuscript to a SpringerOpen ${ }^{\circ}$ journal and benefit from:}

- Convenient online submission

- Rigorous peer review

- Open access: articles freely available online

- High visibility within the field

- Retaining the copyright to your article

Submit your next manuscript at $\boldsymbol{\nabla}$ springeropen.com 